\title{
Therapeutic effects of hippotherapy in the elderly: a review of the literature
}

\author{
Luisa Gámez-Calvo', José M. Gamonales', Kiko Léon', Jesús Muñoz-Jiménez¹,2 \\ 'Universidad de Extremadura. Cáceres. España. 'Universidad Autónoma de Chile. Chile.
}

doi: 10.18176/archmeddeporte.00044

Recibido: $16 / 11 / 2020$ Aceptado: $28 / 01 / 2021$

Key words: Benefits.

\section{Summary}

The present work aims to carry out a structured and bibliographic review based on the results found regarding the terms Hippotherapy and Elderly people. For the reference search, the following keywords in English, Hippotherapy and Elderly, were used as descriptors, these keywords being always entered in databases of the same language. The computerized databases SCOPUS, WOS, SPORTDiscus were used. PubMed and Cochrane. To limit the search for documents, four inclusion criteria were introduced: i) Mention at least some of the characteristics of Hippotherapy for the elderly (minimum 20 words that mention the subject), ii) Select only scientific documents (journal articles) These articles may have an experimental design or be review articles, iii) Be accessible and be available in full text or with access to the abstract, and iiii) Be written in Spanish, English or Portuguese. The results show that the papers on Hippotherapy in the elderly address different research topics and show that equestrian therapies have beneficial therapeutic effects in the elderly population. Hippotherapy interventions improve static balance and dynamic balance, postural balance, functional mobility, flexibility, muscular strength, gait and cadence of steps. They reduce spasticity, causing a decrease in the risk of falls and an improvement in the quality of life of the elderly. In addition, they cause benefits on a psychological level, reducing levels of stress and depression, which produces an improvement in the quality of sleep and positively influences mood.
Palabras clave: Hipoterapia. Personas mayores. Beneficios.

\section{Efectos terapéuticos de la hipoterapia para personas mayores: revisión de la literatura}

\section{Resumen}

El presente trabajo tiene por objetivo realizar una revisión bibliográfica y estructurada basada en los resultados encontrados en torno a los términos Hipoterapia y Personas mayores. Para la búsqueda de referencias, se utilizó como descriptores las siguientes palabras clave en inglés, Hippotherapy y Elderly, siendo estas palabras clave siempre introducidas en las bases de datos del mismo idioma. Se utilizaron las bases de datos informatizadas SCOPUS, WOS, SPORTDiscus. PubMed y Cochrane. Para limitar la búsqueda de documentos, se introdujeron cuatro criterios de inclusión: i) Mencionar al menos alguna de las características de la Hipoterapia para personas mayores (mínimo 20 palabras que mencionen la temática), ii) Seleccionar solamente documentos científicos (Artículos de revistas), pudiendo tener estos manuscritos un diseño experimental o ser estudio de revisión, iii) Ser accesible y estar disponible a texto completo o con acceso al resumen, y iiii) Estar escrito en el idioma español, inglés o portugués. Los resultados muestran que los documentos sobre Hipoterapia en personas mayores abordan tópicos de investigación diferentes, y muestran que las terapias ecuestres tienen efectos terapéuticos beneficiosos en la población de edad avanzada. Las intervenciones con Hipoterapia mejoran el equilibrio estático y el equilibrio dinámico, el equilibrio postural, la movilidad funcional, la flexibilidad, la fuerza muscular, el modo de andar y la cadencia de pasos. Disminuyen la espasticidad, provocando una disminución del riesgo de caída y una mejora de la calidad de vida de las personas de edad avanzada. Además, provocan beneficios a nivel psicológico, reduciendo los niveles de estrés y depresión, lo que produce una mejora en la calidad del sueño e influye positivamente en el estado de ánimo. 


\section{Introduction}

Animal-assisted therapies, specifically with horses, are officially practised almost everywhere in the world', as a therapeutic alternative within the areas of rehabilitation and re-education. This is a specialised work methodology ${ }^{2}$, that has shown improvements in the quality of life and general state of health of individuals ${ }^{3}$, by providing psychological, social and educational benefits that improve the performance of daily activities ${ }^{4,5}$. To conduct this technique, the horse first needs to be trained and must also have a docile nature so that it can be approached by, and come into contact with people who may have behavioural disorders, involuntary movements or who use some kind of device (walking stick or wheelchair), conditions which could scare an untrained horse ${ }^{6}$. It is therefore a direct intervention with some pre-designed goals, for the purpose of achieving physical, social, emotional and cognitive benefits, individually or in a group of persons with different abilities, taking advantage of the characteristics of the animals.

Furthermore, studies have also reported evidence of the effectiveness and benefits of Hippotherapy in different groups of disabled persons, such as with cerebral palsy ${ }^{7,8}$, psychomotor retardation ${ }^{9}$, multiple sclerosis ${ }^{10}$, Down syndrome ${ }^{11}$, or the elderly ${ }^{4,12,13}$, among others. Hippotherapy is a comprehensive, neurologically based, multidisciplinary treatment that uses the horse as its main element, taking advantage of its qualities (movement, rhythm and heat) to stimulate multiple psychomotor and sensory areas ${ }^{9,14}$. It has therefore become an effective intervention, and there is increasing scientific evidence of its benefits, acting across the board in the social, physical and intellectual sphere of participants ${ }^{15}$.

On the other hand, ageing is a natural, inevitable process ${ }^{16}$. Population growth together with increased life expectancy is leading to a considerable increase in the number of elderly persons in developing countries ${ }^{17}$, causing an increase in chronic ageing-related diseases ${ }^{18}$. As a result, the ageing process entails biological, cognitive and social changes, with the progressive presence of molecular and cellular damage ${ }^{19}$, as well as a loss of muscle power and strength ${ }^{20}$. These factors can cause an alteration of physical functions that have a negative impact on the functional daily life skills, and usually accompanied by a concern for the cognitive change occurring ${ }^{21}$, as well as frame of mind ${ }^{22}$.

Given the scarcity of review documents on this subject, and analysing the different databases, a new review of the literature to complete the state-of-the-art with regard to investigations into the use of Hippotherapy in the elderly and to provide conclusions on the benefits of equine therapies for this group, was considered to be of interest.

\section{Material and method}

\section{Design}

This investigation comes within theoretical studies. For this purpose, a search and compilation process was made of scientific documents using the "Data accumulation and study selection" model"23, in order to analyse the articles published in relation to the benefits of Hippotherapy in the elderly.

\section{Sample}

The sample consisted in articles from scientific journals. From a total of 1292 articles in the initial phase of the search, conducted in October 2020 among the three databases, using Hippotherapy as the first term selected, 1243 articles were subsequently rejected after including the second term Elderly. 15 documents were then selected, which met the inclusion criteria pre-established by the investigators.

\section{Criteria for the selection of studies}

For the document search and selection, the following key words were used: Hippotherapy and Elderly. Furthermore, the documents selected to be part of the sample had to meet a series of inclusion criteria (Table 1). The following computerized databases were used, which store the main scientific publications on any field of knowledge: SCOPUS, WOS, SPORTDiscus, PubMed and Cochrane.

\section{Coding of the variables}

The documents selected were classified, based on the following criteria: Title, Author(s), Year, Keywords, Database, Abstract, Type of study, Sample, Benefits and Quality of the documents selected (Table 2).

\section{Study recording procedure and data analysis}

The procedure used for this study is similar to those found in the scientific literature $4,24,25$. Good planning of the literature search is key to success $^{26}$, making it possible to draw relevant conclusions ${ }^{24}$. All the documents selected for the study met the inclusion criteria established.

\section{Table 1 Document inclusion and exclusion criteria.}

\begin{tabular}{|c|c|}
\hline No. & Inclusion criteria \\
\hline 1 & $\begin{array}{l}\text { Mention at least some of the characteristics of } \\
\text { Hippotherapy for the elderly (minimum } 20 \text { words). }\end{array}$ \\
\hline 2 & Select only scientific documents (articles from journals). \\
\hline 3 & Full text or abstract available. \\
\hline \multirow[t]{2}{*}{4} & Written in Spanish, English or Portuguese. \\
\hline & Exclusion criteria \\
\hline 5 & $\begin{array}{l}\text { Exclude those documents in which only the keywords } \\
\text { entered in the databases are mentioned. }\end{array}$ \\
\hline 6 & $\begin{array}{l}\text { Exclude those articles based solely on mechanical horse-riding } \\
\text { simulators. }\end{array}$ \\
\hline 7 & Leave out documents that cannot be referenced. \\
\hline 8 & Exclude articles that only refer to the elderly. \\
\hline
\end{tabular}


Table 2. Characteristics of the literature review study variables.

\begin{tabular}{|c|c|}
\hline Variable & Description \\
\hline Title & Title in English of selected article. \\
\hline Author(s) & $\begin{array}{l}\text { Scientific name of each author of selected } \\
\text { document. }\end{array}$ \\
\hline Year & Year of official publication of selected article. \\
\hline Keywords & Keywords used in article. \\
\hline Database & Data platform providing access to selected article. \\
\hline Summary & $\begin{array}{l}\text { Brief indication of the principal ideas and objective(s) } \\
\text { of selected document. }\end{array}$ \\
\hline Type of study & $\begin{array}{l}\text { Classification of selected articles based on study } \\
\text { type according to Montero \& Leon (2007): } \\
\text { Theoretical studies, Empirical studies with } \\
\text { quantitative methodology \& Qualitative empirical } \\
\text { studies. }\end{array}$ \\
\hline Sample & $\begin{array}{l}\text { Set of individuals or data randomly chosen, which } \\
\text { are considered to be representative of the group to } \\
\text { hich they belong and which are taken to study. }\end{array}$ \\
\hline Benefits & $\begin{array}{l}\text { Indication of the beneficial effects of Hippotherapy } \\
\text { in the elderly. }\end{array}$ \\
\hline Quality of the & $\begin{array}{l}\text { Percentage relating to the quality of the documents } \\
\text { documents selected by observers external to the } \\
\text { investigation. }\end{array}$ \\
\hline
\end{tabular}

Figure 1 sets out the search process conducted for this work.

- Phase 1 Planning and selecting of the keywords for the search. For the selection of the key words, account was taken of the objectives of the literature review relating to the benefits of Hippotherapy for the elderly. In order to locate the highest number of related scientific documents (journal articles), a search was made using the keywords in English "Hippotherapy" and "Elderly". The aforementioned inclusion criteria were established (Table 1). The same keywords, and the same order were used in all the databases consulted.

- Phase 2Database search. Five bibliographic searches were made in the following computerized databases: SCOPUS, WOS, SPORTDisCUS, PubMed and Cochrane. To do so, the same Boolean search procedure (And) was used in each database for the purpose of finding the greatest possible number of related documents. The final search phrase was: Hippotherapy - And - Elderly. The documents selected for the study met the inclusion criteria established. The document search structure in the different databases is shown in Figure 2. As keywords were progressively added in the search engine, the results decreased considerably. The document inclusion and exclusion criteria were subsequently applied.

- Phase 3 Access to documents. Some of the databases used for the search for references do not allow access to full-text documents. Therefore, in order to consult the greatest number of original fulltext articles, the web portal of the electronic library of the University
Figure 1. Flow diagram of the bibliographic search process.

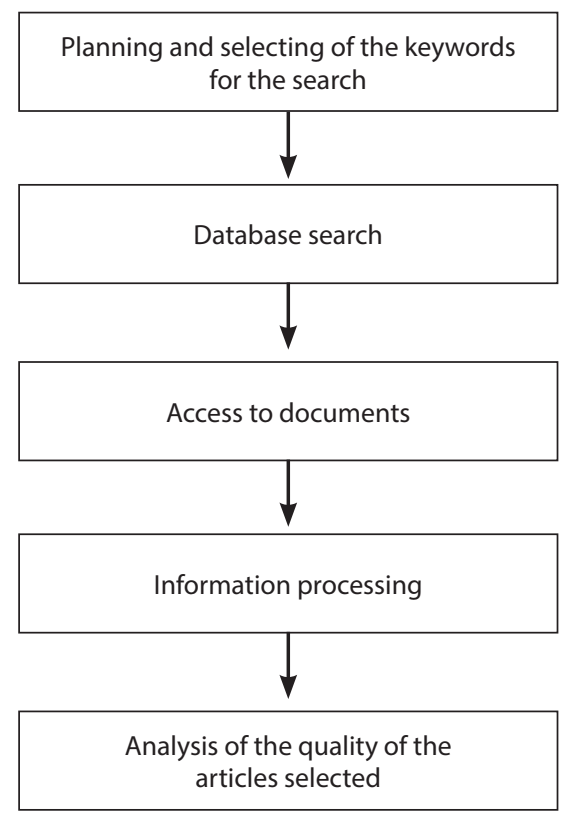

of Extremadura was used, as well as different platforms and web search engines to contact the authors ${ }^{7,25}$. The sample was reduced to 15 articles, which were reviewed in depth. The number of documents selected must not be too large given that the processing of the information could be contaminated by the researcher ${ }^{27}$.

- Phase 4 Processing of information. For each article, an analysis was made of the Title, Author(s), Year, Keywords, Database, Abstract, Study type, Sample, Benefits and Quality. For this purpose, it is important to organise and categorize all the information obtained ${ }^{7}$. Furthermore, a summary of each document was made, by preparing a table with all the information that would allow for an optimal and efficient review. Likewise, a descriptive analysis was made of the following variables: Year, Keywords and Databases in the various articles in order to identify their relationship with the study topic, as conducted by the authors 5 . For those articles with no keywords, the investigators themselves determined a series of terms, based on the subject of the study. Finally, the main benefits of Hippotherapy for the elderly were drawn from the selected articles. Figure 3 shows the main keywords used in the selected journal articles. Furthermore, Figure 4 shows the number of articles selected based on the Year of publication, and Figure 5 shows the number of articles selected based on the Database. These statistical analyses provide the link with the objective of this study, and also make it possible to identify a larger amount of relevant information related to the documents selected. 
Figure 2. Schematic of the documents found in the different databases.

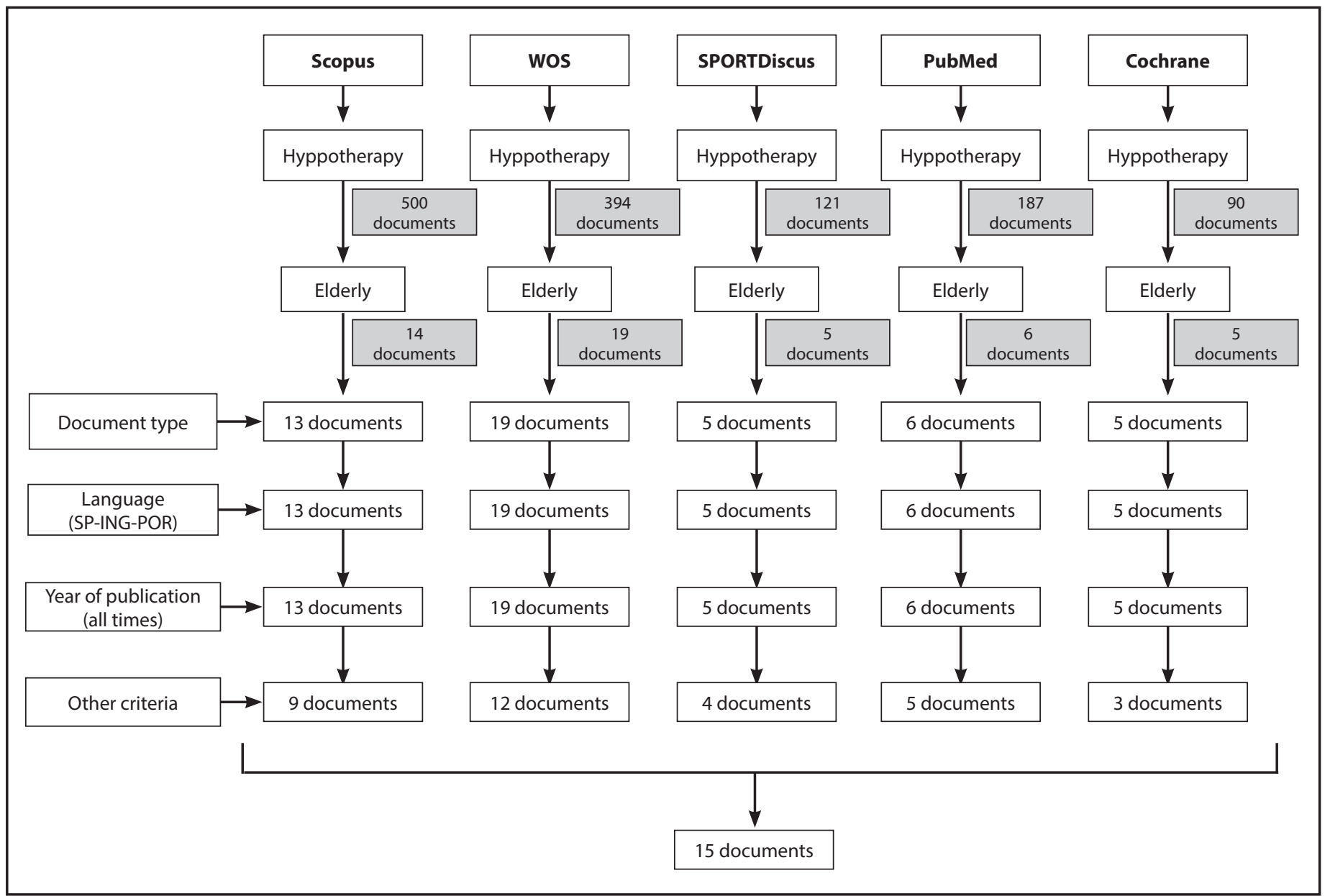

- Phase 5 Analysis of the quality of the articles selected. For the analysis of the quality of each study, a quality questionnaire was prepared, similar to the one proposed by the authors ${ }^{28}$. This questionnaire comprised 16 questions with either a Yes or No answer (Table 3). Furthermore, the evaluation process was conducted by 3 outside observers (holding a Degree in Physical Activity and Sport Sciences) and with a deep knowledge of the study subject (Table 4). The studies analysed were assessed according to purpose (Q1), bibliographical data/background (Q2), design (Q3), sample (Q4 and Q5), the use of informed consent (Q6), measurements and result (Q7 and Q8), method and description (Q9), the importance of the results $(\mathrm{Q} 10)$, the methods of analysis (Q11), information on the practical importance (Q12), subject drop-outs (Q13), conclusions (Q14), practical implications (Q15) and the study limitations (Q16). The 16 document quality criteria were given a score on a binary scale (Yes=1/No=0). Each article was classified as (A) Excellent methodological quality, with a score $>75 \%$ (B) Good methodological quality, with a score from $51 \%$ to $75 \%$, and (C) Poor methodological quality, with a score $<50 \%$. For the review articles, those questions that could not be answered by the methodology used, were assumed to be $1=$ Yes.

\section{Results}

The results are shown in the same order in which the bibliographic review was conducted. Table 5 shows the different articles and their main characteristics regarding the benefits of Hippotherapy in the elderly, based on the criteria defined in the method. Moreover, they are shown in chronological order, for ease of reading.

\section{Discussion}

This study updates the state of knowledge with regard to the benefits of Hippotherapy for the elderly, using methodological procedures that are similar to those existing in the scientific literature ${ }^{23-25}$, identifying and classifying the most relevant information. Furthermore, it serves as a basis for future reviews while also making it possible to draw relevant conclusions. On the other hand, it has made it possible to analyse the 
Figure 3. Main keywords relating to the benefits of Hippotherapy in the elderly.

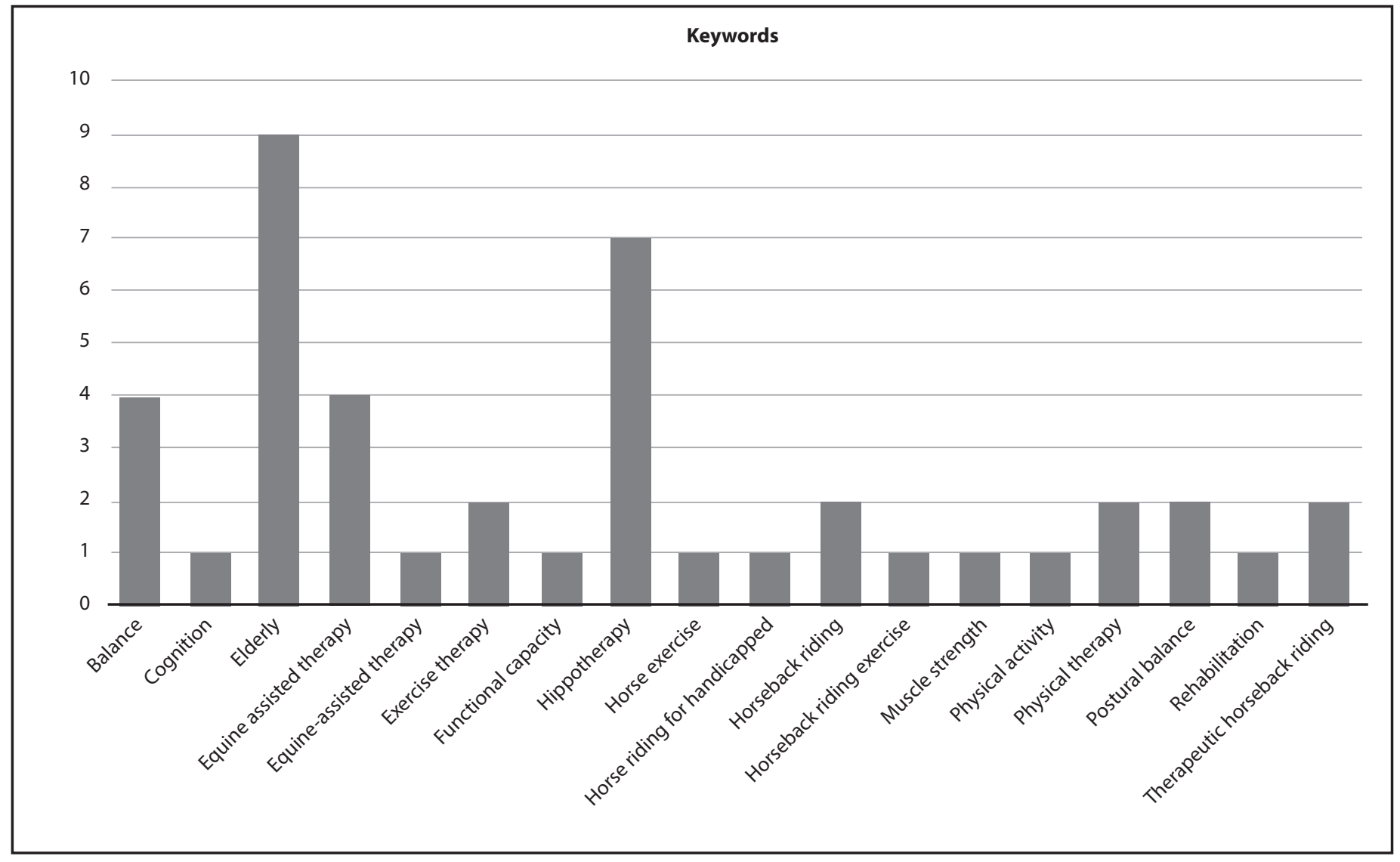

Figure 4. Number of documents selected based on the year of publication.

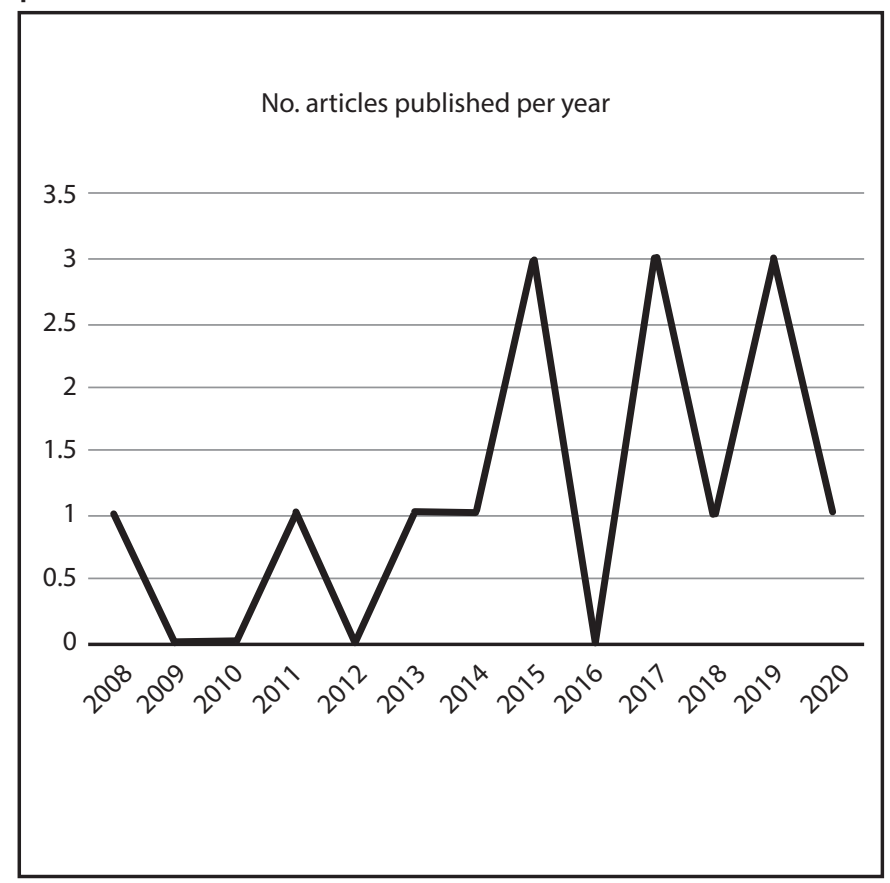

Figure 4. Number of documents selected based on the database.

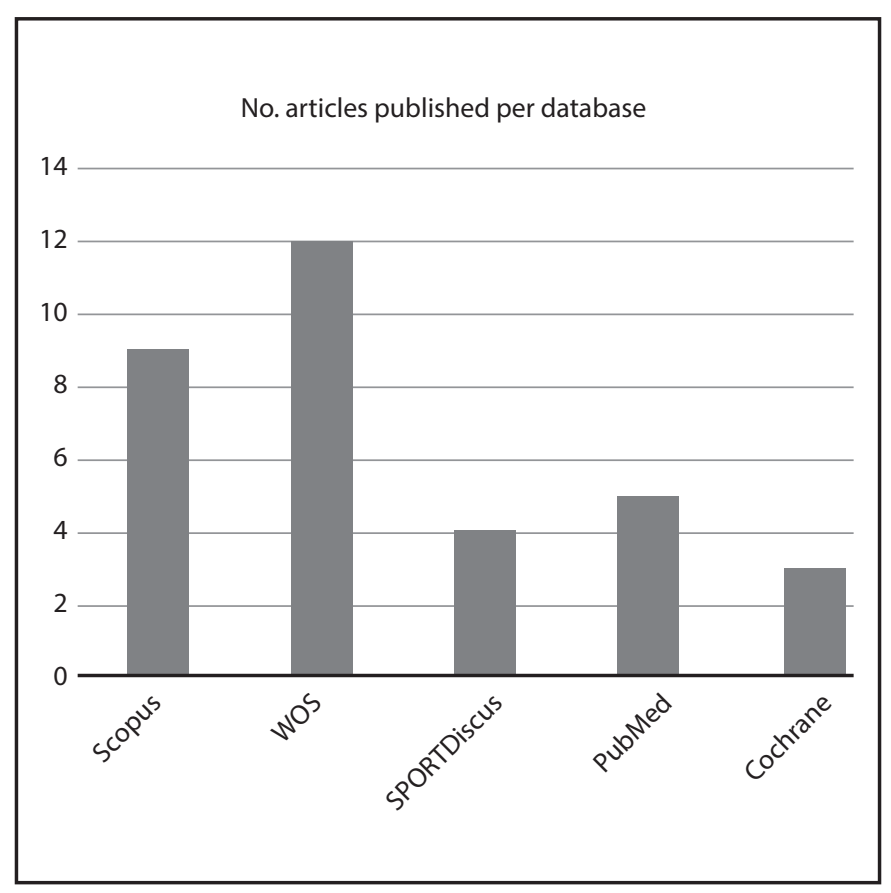


Table 3. Article quality criteria.

\begin{tabular}{|c|c|c|c|}
\hline Q1 & Was the purpose of the study clearly indicated? & $1=$ Yes & $0=$ No \\
\hline Q2 & Did the authors review the relevant background literature? & $1=$ Yes & $0=\mathrm{No}$ \\
\hline Q3 & Was the design appropriate for the investigation question? & $1=$ Yes & $0=\mathrm{No}$ \\
\hline Q4 & Was the sample described in detail? & $1=$ Yes & $0=$ No \\
\hline Q5 & Was the sample size accounted for? & $1=$ Yes & $0=\mathrm{No}$ \\
\hline Q6 & Was informed consent obtained? (If not described, assume that this was not so) & $1=$ Yes & $0=\mathrm{No}$ \\
\hline Q7 & Were the result measurements reliable? (If not described, assume that this was not so) & $1=$ Yes & $0=\mathrm{No}$ \\
\hline Q8 & Were the result measurements valid? (If not described, assume that this was not so) & $1=$ Yes & $0=\mathrm{No}$ \\
\hline Q9 & Was the method described in detail? & $1=$ Yes & $0=\mathrm{No}$ \\
\hline Q10 & Were the results reported in terms of statistical significance? & $1=$ Yes & $0=\mathrm{No}$ \\
\hline Q11 & Were the analysis methods approved? & $1=$ Yes & $0=\mathrm{No}$ \\
\hline Q12 & Was the importance of the practice reported? & $1=$ Yes & $0=\mathrm{No}$ \\
\hline Q13 & Was the drop-out rate reported? & $1=$ Yes & $0=\mathrm{No}$ \\
\hline Q14 & Were the conclusions appropriate given the study methods? & $1=$ Yes & $0=\mathrm{No}$ \\
\hline Q15 & Are there any implications for the practice given the results of the study? & $1=$ Yes & $0=\mathrm{No}$ \\
\hline Q16 & Are the study limitations recognised and described by the authors? & $1=$ Yes & $0=\mathrm{No}$ \\
\hline
\end{tabular}

Table 4. Article quality analysis

\begin{tabular}{|c|c|c|c|c|c|}
\hline Documents & Observer 1 & Observer 2 & Observer 3 & Mean & Quality \\
\hline 1 & 62.5 & 62.5 & 68.75 & 64.583 & C \\
\hline 2 & 81.25 & 87.5 & 75 & 81.250 & A \\
\hline 3 & 75 & 75 & 87.5 & 79.167 & A \\
\hline 4 & 87.5 & 87.5 & 87.5 & 87.500 & A \\
\hline 5 & 75 & 81.25 & 81.25 & 79.167 & A \\
\hline 6 & 81.25 & 75 & 75 & 77.083 & A \\
\hline 7 & 100 & 100 & 100 & 100,000 & A \\
\hline 8 & 100 & 100 & 100 & 100,000 & A \\
\hline 9 & 100 & 100 & 100 & 100,000 & A \\
\hline 10 & 81,25 & 81,25 & 81.25 & 81,250 & A \\
\hline 11 & 87,5 & 87,5 & 87.5 & 87,500 & A \\
\hline 12 & 93,75 & 87,5 & 87.5 & 89,583 & A \\
\hline 13 & 87,5 & 87,5 & 87.5 & 87,500 & A \\
\hline 14 & 87,5 & 93,75 & 93.75 & 91,667 & A \\
\hline 15 & 87,5 & 87,5 & 87.5 & 87,500 & $A$ \\
\hline
\end{tabular}

A: Excellent methodological quality; B: Good methodological quality; C: Poor methodological quality.

main components of Hippotherapy and to determine their benefits, identifying how the sessions should be addressed in order to achieve a positive effect on the elderly. For this purpose, different techniques to access the information were used, preparing a bibliographic review of the documents selected. Following the review process, a wide variety of study Types were found, ranging from theoretical to quantitative. All the studies agree that the main problems caused by ageing are loss of balance, strength and muscle mass, as well as the risk of falls. On the other hand, account should be taken of the individual characteristics of each participant, given that each person is different and will have a different response, also considering the "active and healthy ageing" approach ${ }^{29}$, which considers that each subject will have a different rate of senescence.

The theoretical studies conducted ${ }^{13,30,31}$ concluded that Hippotherapy or therapeutic horse-riding is beneficial to the elderly. All underscore improved balance and postural control, with the subsequent decrease in the risk of falls. However, a more recent review ${ }^{32}$ suggests that the current studies on Equine-Assisted Therapies (hereinafter EAT) are methodologically weak, poorly designed, have a small sample and many of these studies lack control groups and details on the intervention 
Table 5. Principal investigations and characteristics regarding the benefits of Hippotherapy in the elderly.

\begin{tabular}{|c|c|c|c|c|c|c|c|c|c|}
\hline Title & Author & Year & Keywords & B & Abstract & Type & Sample & Benefits & Quality \\
\hline $\begin{array}{l}\text { The use of } \\
\text { hippotherapy } \\
\text { as therapeutic } \\
\text { resource to } \\
\text { improve the } \\
\text { static balance } \\
\text { in elderly } \\
\text { individuals }\end{array}$ & $\begin{array}{l}\text { Toigo, Júnior, } \\
\text { Pinto \& Ávila }\end{array}$ & 2008 & $\begin{array}{l}\text { Physical Therapy } \\
\text { Musculoskeletal, } \\
\text { Equilibrium, } \\
\text { Exercise } \\
\text { movement, } \\
\text { Epidemiology } \\
\text { experimental, } \\
\text { Women, Middle } \\
\text { aged, Aged }\end{array}$ & wos & $\begin{array}{l}\text { Hippotherapy as a } \\
\text { means to improve static } \\
\text { balance in the elderly. } \\
\text { Experimental study } \\
\text { with a pre- and post- } \\
\text { test Healthy, elderly } \\
\text { individuals experience } \\
\text { balance alterations, } \\
\text { Hippotherapy serves to } \\
\text { improve balance. }\end{array}$ & $\begin{array}{l}\text { Quantitative } \\
\text { study }\end{array}$ & $\begin{array}{l}10 \text { women } \\
\text { aged from } 60 \\
\text { to } 74 \text { years }\end{array}$ & $\begin{array}{l}\text { Improvements } \\
\text { in static } \\
\text { balance and } \\
\text { reduction in } \\
\text { risk of falls. }\end{array}$ & 64,583 \\
\hline $\begin{array}{l}\text { Effect of } \\
\text { equine- } \\
\text { assisted } \\
\text { therapy on } \\
\text { the postural } \\
\text { balance of } \\
\text { the elderly }\end{array}$ & $\begin{array}{l}\text { Araujo, Silva, } \\
\text { Costa, Pereira } \\
\text { \& Safons }\end{array}$ & 2011 & $\begin{array}{l}\text { Equine-assisted } \\
\text { therapy, Postural } \\
\text { balance, Elderly, } \\
\text { Physical therapy, } \\
\text { Rehabilitation }\end{array}$ & $\begin{array}{l}\text { WOS/ } \\
\text { Scopus/ } \\
\text { PubMed/ } \\
\text { SPORT } \\
\text { Discus }\end{array}$ & $\begin{array}{l}\text { Determine whether } \\
\text { Hippotherapy produces } \\
\text { alterations in the } \\
\text { balance of the elderly. } \\
\text { Old age tends to } \\
\text { normalise stabilometric } \\
\text { measurements, } \\
\text { however horse assisted } \\
\text { interventions lead to a } \\
\text { significant improvement } \\
\text { in balance as well as a } \\
\text { reduction in the risk of } \\
\text { falls. }\end{array}$ & $\begin{array}{l}\text { Quantitative } \\
\text { study }\end{array}$ & $\begin{array}{l}17 \text { elderly } \\
\text { individuals }\end{array}$ & $\begin{array}{l}\text { Reduces the } \\
\text { risks of falls in } \\
\text { the elderly. }\end{array}$ & 81,250 \\
\hline $\begin{array}{l}\text { Effects of } \\
\text { hippotherapy } \\
\text { on mobility, } \\
\text { strength and } \\
\text { balance in } \\
\text { elderly }\end{array}$ & $\begin{array}{l}\text { Araújo, De } \\
\text { Oliveira, } \\
\text { Martins, } \\
\text { De Moura- } \\
\text { Pereira, } \\
\text { Copetti \& } \\
\text { Safons }\end{array}$ & 2013 & $\begin{array}{l}\text { Hippotherapy, } \\
\text { Muscle strength, } \\
\text { Postural balance, } \\
\text { Gait, Elderly. }\end{array}$ & $\begin{array}{l}\text { WOS/ } \\
\text { Scopus/ } \\
\text { PubMed/ } \\
\text { Cochrane }\end{array}$ & $\begin{array}{l}\text { Evaluates the chronic } \\
\text { effects of Hippotherapy } \\
\text { on functional mobility, } \\
\text { muscle strength and } \\
\text { balance in elderly } \\
\text { individuals. }\end{array}$ & $\begin{array}{l}\text { Quantitative } \\
\text { study }\end{array}$ & $\begin{array}{l}28 \text { individuals } \\
\text { aged from } 60 \\
\text { to } 84 \text { years, } \\
\text { men and } \\
\text { women }\end{array}$ & $\begin{array}{l}\text { Improves } \\
\text { the strength } \\
\text { of the lower } \\
\text { limbs and } \\
\text { balance in the } \\
\text { elderly. }\end{array}$ & 79,167 \\
\hline $\begin{array}{l}\text { The Effects of } \\
\text { Hippotherapy } \\
\text { on Elderly } \\
\text { Persons' Static } \\
\text { Balance and } \\
\text { Gait }\end{array}$ & Kim \& Lee & 2014 & $\begin{array}{l}\text { Elderly, Balance, } \\
\text { Hippotherapy }\end{array}$ & $\begin{array}{l}\text { WOS/ } \\
\text { Scopus/ } \\
\text { PubMed/ } \\
\text { Cochrane }\end{array}$ & $\begin{array}{l}\text { Examines the effects of } \\
\text { Hippotherapy on the } \\
\text { static balance and gait of } \\
\text { the elderly. }\end{array}$ & $\begin{array}{l}\text { Quantitative } \\
\text { study }\end{array}$ & $\begin{array}{l}30 \text { elderly } \\
\text { individuals }\end{array}$ & $\begin{array}{l}\text { Improves } \\
\text { the static } \\
\text { and dynamic } \\
\text { balance of the } \\
\text { elderly. }\end{array}$ & 87,500 \\
\hline $\begin{array}{l}\text { Effects of } \\
\text { horseback ri- } \\
\text { ding exercise } \\
\text { therapy on } \\
\text { hormone le- } \\
\text { vels in elderly } \\
\text { persons }\end{array}$ & $\begin{array}{l}\text { Sung-Hyoun, } \\
\text { Jin-Woo, } \\
\text { Seon-Rye \& } \\
\text { Byung-Jun }\end{array}$ & 2015 & $\begin{array}{l}\text { Hormone, } \\
\text { Exercise therapy, } \\
\text { Horseback riding }\end{array}$ & wos & $\begin{array}{l}\text { Determines the effects } \\
\text { of horse-riding on the } \\
\text { normal hormone levels of } \\
\text { the elderly. Horse therapy } \\
\text { produces a significant } \\
\text { increase in serotonin and } \\
\text { cortisol }\end{array}$ & $\begin{array}{l}\text { Quantitative } \\
\text { study }\end{array}$ & $\begin{array}{l}20 \text { elderly } \\
\text { individuals }\end{array}$ & $\begin{array}{l}\text { Increased } \\
\text { serotonin and } \\
\text { cortisol levels. }\end{array}$ & 79,167 \\
\hline $\begin{array}{l}\text { Effects of } \\
\text { horseback } \\
\text { riding exerci- } \\
\text { se therapy on } \\
\text { background } \\
\text { electroen- } \\
\text { cephalo- } \\
\text { grams of } \\
\text { elderly } \\
\text { people }\end{array}$ & $\begin{array}{l}\text { Kim, Cho, } \\
\text { Kim, Lee, } \\
\text { Brienen \& } \\
\text { Cho }\end{array}$ & 2015 & $\begin{array}{l}\text { Exercise therapy, } \\
\text { Electroencepha- } \\
\text { logra, Horseback } \\
\text { riding }\end{array}$ & WOS & $\begin{array}{l}\text { Analyses the effect of } \\
\text { horse-riding therapy on } \\
\text { the electroencephalo- } \\
\text { grams of the elderly. It } \\
\text { suggests that horse-riding } \\
\text { therapy improves it. }\end{array}$ & $\begin{array}{l}\text { Quantitative } \\
\text { study }\end{array}$ & $\begin{array}{l}20 \text { elderly } \\
\text { individuals }\end{array}$ & $\begin{array}{l}\text { The alpha } \\
\text { power index } \\
\text { increased sig- } \\
\text { nificantly after } \\
\text { horse riding, } \\
\text { suggesting } \\
\text { that the exer- } \\
\text { cise improved } \\
\text { the electroen- } \\
\text { cephalogram. }\end{array}$ & 77,083 \\
\hline
\end{tabular}




\begin{tabular}{|c|c|c|c|c|c|c|c|c|c|}
\hline Title & Author & Year & Keywords & B & Abstract & Type & Sample & Benefits & Quality \\
\hline $\begin{array}{l}\text { Comparative } \\
\text { Effects of } \\
\text { Horse Exer- } \\
\text { cise Versus } \\
\text { Traditional } \\
\text { Exercise } \\
\text { Programs on } \\
\text { Gait, Muscle } \\
\text { Strength, and } \\
\text { Body Balance } \\
\text { in Healthy } \\
\text { Older Adults }\end{array}$ & $\begin{array}{l}\text { Aranda-Gar- } \\
\text { cía, Iricibar, } \\
\text { Planas, } \\
\text { Prat-Subirana, } \\
\text { \&. Angulo- } \\
\text { Barroso }\end{array}$ & 2015 & $\begin{array}{l}\text { Elderly, Physical } \\
\text { Activity, Horse } \\
\text { Exercise, } \\
\text { Follow-Up Study, } \\
\text { Rural Community }\end{array}$ & wOS & $\begin{array}{l}\text { Evaluates and compares } \\
\text { the effect of } 2 \text { physical } \\
\text { exercise programs, one } \\
\text { traditional and the other } \\
\text { on horseback, with } \\
\text { regard to the physical } \\
\text { and functional capacity of } \\
\text { healthy elderly indivi- } \\
\text { duals. Horse exercises } \\
\text { could be an alternative to } \\
\text { traditional physical exerci- } \\
\text { ses for the elderly. }\end{array}$ & $\begin{array}{l}\text { Quantitative } \\
\text { study }\end{array}$ & $\begin{array}{l}38 \text { healthy } \\
\text { individuals } \\
\text { aged over } 60 \\
\text { years } \\
(\mathrm{TE}=17, \\
\mathrm{HE}=10 \text {, } \\
\mathrm{CG}=11)\end{array}$ & $\begin{array}{l}\text { Horse exercise } \\
\text { is a viable } \\
\text { activity to } \\
\text { maintain } \\
\text { or improve } \\
\text { the physical } \\
\text { functions of } \\
\text { the elderly. It } \\
\text { leads to im- } \\
\text { provements } \\
\text { in gait speed, } \\
\text { maximum } \\
\text { isometric } \\
\text { force of the } \\
\text { knee extensor } \\
\text { muscles. }\end{array}$ & 100,000 \\
\hline $\begin{array}{l}\text { Equine-assis- } \\
\text { ted therapy } \\
\text { intervention } \\
\text { studies targe- } \\
\text { ting physical } \\
\text { symptoms in } \\
\text { adults: A } \\
\text { systematic } \\
\text { review }\end{array}$ & $\begin{array}{l}\text { White-Lewis, } \\
\text { Russell, } \\
\text { Johnson, } \\
\text { Cheng \& } \\
\text { McClain }\end{array}$ & 2017 & $\begin{array}{l}\text { Equine assisted } \\
\text { therapy, } \\
\text { Therapeutic } \\
\text { horse riding, } \\
\text { Therapeutic } \\
\text { horseback riding, } \\
\text { Hippotherapy, } \\
\text { Equine } \\
\text { psychotherapy, } \\
\text { Equine facilitated } \\
\text { therapy, Horse } \\
\text { riding for } \\
\text { handicapped, } \\
\text { Equus. }\end{array}$ & Scopus & $\begin{array}{l}\text { Systematic review analy- } \\
\text { sing the evidence and } \\
\text { quality of Hippotherapy } \\
\text { studies. }\end{array}$ & $\begin{array}{l}\text { Theoretical } \\
\text { study }\end{array}$ & & $\begin{array}{l}\text { Improved } \\
\text { balance, plas- } \\
\text { ticity, muscle } \\
\text { strength, gait } \\
\text { and cadence } \\
\text { as well as } \\
\text { quality of } \\
\text { life. Impro- } \\
\text { vements at } \\
\text { a biological, } \\
\text { psychological } \\
\text { and social } \\
\text { level. }\end{array}$ & 100,000 \\
\hline $\begin{array}{l}\text { Therapeutic } \\
\text { Effects of } \\
\text { Horseback } \\
\text { Riding } \\
\text { Interventions: } \\
\text { A Systematic } \\
\text { Review and } \\
\text { Meta-analysis }\end{array}$ & $\begin{array}{l}\text { Stergiou, } \\
\text { Tzoufi, Ntzani, } \\
\text { Varvarousis, } \\
\text { Beris \& } \\
\text { Ploumis }\end{array}$ & 2017 & $\begin{array}{l}\text { Therapeutic } \\
\text { Horseback Riding, } \\
\text { Hippotherapy, } \\
\text { Cerebral Palsy, } \\
\text { Multiple Sclerosis, } \\
\text { Neuromuscular } \\
\text { Disease, Elderly, } \\
\text { Stroke, Neuro- } \\
\text { motor; Physical } \\
\text { Disabilities. }\end{array}$ & $\begin{array}{l}\text { Scopus/ } \\
\text { SPORT } \\
\text { Discus }\end{array}$ & $\begin{array}{l}\text { Studies the possible po- } \\
\text { sitive effects of EAT, both } \\
\text { at a physical and mental } \\
\text { level. The EAT are feasible } \\
\text { interventions for patients } \\
\text { with balance, gait and } \\
\text { psychomotor problems. }\end{array}$ & $\begin{array}{l}\text { Theoretical } \\
\text { study }\end{array}$ & & $\begin{array}{l}\text { Improves } \\
\text { balance, } \\
\text { gait and } \\
\text { psychomotor } \\
\text { disorders. }\end{array}$ & 100,000 \\
\hline $\begin{array}{l}\text { Effects of } \\
\text { horseback } \\
\text { riding } \\
\text { exercise on } \\
\text { the relative } \\
\text { alpha power } \\
\text { spectrum in } \\
\text { the elderly }\end{array}$ & $\begin{array}{l}\text { Sung-Hyoun } \\
\text { Cho }\end{array}$ & 2017 & $\begin{array}{l}\text { Horseback riding } \\
\text { exercise } \\
\text { Relative a-power } \\
\text { spectrum } \\
\text { Elderly } \\
\text { Slow alpha } \\
\text { power } \\
\text { Fast alpha power }\end{array}$ & $\begin{array}{l}\text { Scopus/ } \\
\text { WOS/ } \\
\text { Cochrane }\end{array}$ & $\begin{array}{l}\text { Identification of the } \\
\text { effects of horse-riding and } \\
\text { the mechanical simula- } \\
\text { tor on the alpha power } \\
\text { spectrum in the elderly. } \\
\text { Both interventions have } \\
\text { a positive effect on the } \\
\text { psychological stability of } \\
\text { the elderly. }\end{array}$ & $\begin{array}{l}\text { Quantitative } \\
\text { study }\end{array}$ & $\begin{array}{l}31 \text { individuals } \\
\text { aged over } 65 \\
\text { years }(C G=15 ; \\
S G=16)\end{array}$ & $\begin{array}{l}\text { Improve- } \\
\text { ments in the } \\
\text { high power } \\
\text { electroen- } \\
\text { cephalogram, } \\
\text { activation of } \\
\text { all areas of } \\
\text { the electroen- } \\
\text { cephalogram, } \\
\text { improving } \\
\text { concentration } \\
\text { and rest. } \\
\text { Benefits to } \\
\text { psychological } \\
\text { stability. }\end{array}$ & 81,250 \\
\hline $\begin{array}{l}\text { Effect of } \\
\text { hippotherapy } \\
\text { on older } \\
\text { balance: a } \\
\text { systematic } \\
\text { review with } \\
\text { methanalysis }\end{array}$ & $\begin{array}{l}\text { Araújo, } \\
\text { Martins, } \\
\text { Blasczyk, } \\
\text { Feng, Oliveira, } \\
\text { Copetti \& } \\
\text { Safons }\end{array}$ & 2018 & $\begin{array}{l}\text { Hippotherapy, } \\
\text { Elderly, Balance }\end{array}$ & $\begin{array}{l}\text { WOS/ } \\
\text { SPORT } \\
\text { Discus }\end{array}$ & $\begin{array}{l}\text { Studies the existing } \\
\text { signs of Hippotherapy in } \\
\text { relation to the balance of } \\
\text { the elderly, and concludes } \\
\text { that it has a significant } \\
\text { effect on improving the } \\
\text { postural balance of the } \\
\text { elderly. }\end{array}$ & $\begin{array}{l}\text { Theoretical } \\
\text { study }\end{array}$ & & $\begin{array}{l}\text { Improvement } \\
\text { in the } \\
\text { postural } \\
\text { balance of the } \\
\text { elderly. }\end{array}$ & 87,500 \\
\hline
\end{tabular}




\begin{tabular}{|c|c|c|c|c|c|c|c|c|c|}
\hline Title & Author & Year & Keywords & B & Abstract & Type & Sample & Benefits & Quality \\
\hline $\begin{array}{l}\text { Impact of } \\
\text { hippotherapy } \\
\text { for balance } \\
\text { improvement } \\
\text { and flexibility } \\
\text { in elderly } \\
\text { people }\end{array}$ & $\begin{array}{l}\text { Diniz, De } \\
\text { Mello, Ribeiro, } \\
\text { Lage, Júnior, } \\
\text { Ferreira, Da } \\
\text { Fonseca, } \\
\text { Rosa, Teixeisa, } \\
\text { \& Espindula }\end{array}$ & 2019 & $\begin{array}{l}\text { Balance, } \\
\text { Flexibility, } \\
\text { Elderly, } \\
\text { Horse-assisted } \\
\text { therapy. }\end{array}$ & $\begin{array}{l}\text { WOS/ } \\
\text { Scopus/ } \\
\text { PubMed/ } \\
\text { SPORT } \\
\text { Discus }\end{array}$ & $\begin{array}{l}\text { Information on the impact } \\
\text { of Hippotherapy on the } \\
\text { elderly. Ageing leads to } \\
\text { a decrease in functional } \\
\text { ability, strength, balance, } \\
\text { flexibility, agility and } \\
\text { coordination, due to neu- } \\
\text { rological and muscular } \\
\text { changes. Hippotherapy } \\
\text { improves the functional } \\
\text { mobility, dynamic balance } \\
\text { and flexibility of the } \\
\text { elderly. }\end{array}$ & $\begin{array}{l}\text { Quantitative } \\
\text { study }\end{array}$ & $\begin{array}{l}30 \text { elderly } \\
\text { individuals }\end{array}$ & $\begin{array}{l}\text { Improves the } \\
\text { functional } \\
\text { mobility, } \\
\text { dynamic } \\
\text { balance and } \\
\text { flexibility of } \\
\text { the elderly. }\end{array}$ & 89,583 \\
\hline $\begin{array}{l}\text { An umbrella } \\
\text { review of } \\
\text { the evidence } \\
\text { for equine- } \\
\text { assisted } \\
\text { interventions }\end{array}$ & $\begin{array}{l}\text { Stern \& } \\
\text { Chur-Hansen. }\end{array}$ & 2019 & $\begin{array}{l}\text { Animal-assisted } \\
\text { interventions; } \\
\text { Equine-assisted } \\
\text { interventions; } \\
\text { Hippotherapy; } \\
\text { Systematic re- } \\
\text { views; Umbrella } \\
\text { review. }\end{array}$ & wos & $\begin{array}{l}\text { Review of current EAT } \\
\text { documentation. The evi- } \\
\text { dence from the EAT may } \\
\text { be incorrect. The basis for } \\
\text { the current evidence is } \\
\text { methodologically weak. } \\
\text { Therefore, at present, } \\
\text { therapeutic horse-riding } \\
\text { interventions cannot be } \\
\text { recommended as the best } \\
\text { practice. Higher quality } \\
\text { studies are necessary. }\end{array}$ & $\begin{array}{l}\text { Theoretical } \\
\text { study }\end{array}$ & & $\begin{array}{l}\text { There are } \\
\text { a number } \\
\text { of benefits. } \\
\text { However, } \\
\text { there is a lack } \\
\text { of scientific } \\
\text { evidence. }\end{array}$ & 87,500 \\
\hline $\begin{array}{l}\text { An Explo- } \\
\text { ration of } \\
\text { Equine-Assis- } \\
\text { ted Therapy } \\
\text { to Improve } \\
\text { Balance, } \\
\text { Functional } \\
\text { Capacity, and } \\
\text { Cognition in } \\
\text { Older Adults } \\
\text { with Alzhei- } \\
\text { mer Disease }\end{array}$ & $\begin{array}{l}\text { Borges, } \\
\text { Martins, } \\
\text { Freitas, } \\
\text { Camargos, } \\
\text { Mota \& } \\
\text { Safons }\end{array}$ & 2019 & $\begin{array}{l}\text { Alzheimer } \\
\text { disease, balance, } \\
\text { cognition, } \\
\text { equineassisted } \\
\text { therapy, } \\
\text { unctional } \\
\text { capacity }\end{array}$ & Scopus & $\begin{array}{l}\text { Studies the benefits of } \\
\text { EAT in elderly indivi- } \\
\text { duals with Alzheimer's, } \\
\text { given that physical and } \\
\text { cognitive aspects are } \\
\text { involved. The objectives } \\
\text { are to describe the effects } \\
\text { of the EAT on the balance, } \\
\text { functional capacity and } \\
\text { cognitive level of elderly } \\
\text { individuals diagnosed } \\
\text { with Alzheimer's. The } \\
\text { results show significant } \\
\text { improvements in the } \\
\text { Wilcoxon test. }\end{array}$ & $\begin{array}{l}\text { Quantitative } \\
\text { study }\end{array}$ & $\begin{array}{l}9 \text { elderly } \\
\text { individuals } \\
(79.7 \pm 7.8 \\
\text { years) with } \\
\text { Alzheimer's }\end{array}$ & $\begin{array}{l}\text { Improve- } \\
\text { ments in the } \\
\text { balance and } \\
\text { functional } \\
\text { capacity. } \\
\text { There is no } \\
\text { cognitive } \\
\text { decline. }\end{array}$ & 91,667 \\
\hline $\begin{array}{l}\text { Electrom- } \\
\text { yographic } \\
\text { analysis } \\
\text { of stoma- } \\
\text { tognathic } \\
\text { muscles in } \\
\text { elderly after } \\
\text { hippotherapy }\end{array}$ & $\begin{array}{l}\text { De Mello } \\
\text { Regalo, Diniz, } \\
\text { Lage, Ribeiro, } \\
\text { Bevilacqua } \\
\text { Junior et al., }\end{array}$ & 2020 & $\begin{array}{l}\text { Hippotherapy, } \\
\text { elerdly, Electrom- } \\
\text { yographic } \\
\text { analysis, } \\
\text { stomatognathic } \\
\text { muscles. }\end{array}$ & $\begin{array}{l}\text { WOS/ } \\
\text { Scopus/ } \\
\text { PubMed }\end{array}$ & $\begin{array}{l}\text { Uses electromyography } \\
\text { to evaluate the muscles } \\
\text { of the stomatognathic } \\
\text { system (masseter and } \\
\text { temporalis) in the elderly } \\
\text { before and after partici- } \\
\text { pation in hippotherapy. } \\
\text { Hippotherapy promotes a } \\
\text { reduction in the myoelec- } \\
\text { tric activity of the mas- } \\
\text { tication muscles in the } \\
\text { elderly. }\end{array}$ & $\begin{array}{l}\text { Quantitative } \\
\text { study }\end{array}$ & $\begin{array}{l}17 \text { elderly } \\
\text { individuals } \\
(66.5 \pm 7 \\
\text { years) }\end{array}$ & $\begin{array}{l}\text { Reduction in } \\
\text { the myoelec- } \\
\text { tric activity of } \\
\text { the muscles } \\
\text { involved in } \\
\text { mastication. } \\
\text { (In healthy } \\
\text { subjects there } \\
\text { is less fibre } \\
\text { recruitment to } \\
\text { perform the } \\
\text { same mastica- } \\
\text { tion process, } \\
\text { compared to } \\
\text { persons with } \\
\text { morpho- } \\
\text { functional } \\
\text { changes that } \\
\text { generate } \\
\text { stress and } \\
\text { fatigue). }\end{array}$ & 87,500 \\
\hline
\end{tabular}


made. It would therefore be recommendable to conduct longitudinal studies for the purpose of checking the durability of the benefits of this technique in the elderly.

On the other hand, the Quantitative Studies included in this review have a small sample, the largest one being the work by ${ }^{33}$, with 38 subjects, and which moreover had a control group, while the smallest sample appears in a study conducted by ${ }^{34}$, which only had a sample of 9 elderly persons with Alzheimer's. Most of the Quantitative Studies included in this review ${ }^{12,33,35}$ focus on the beneficial effects of Hippotherapy with regard to balance, gait and the risk of falling in the elderly. It would therefore be recommendable to look at other benefits and to use other data recording tools for the investigations, such as inertial devices. These tools make it possible to quantify the internal and external load placed on users.

The studies conducted by ${ }^{36,37}$, based on a sample of 20 participants, of which 10 were in the control group and 10 in the experimental group, and by ${ }^{38}$, with a sample of 31 participants, 15 in the control group and 16 in the experimental group, both detail the procedure used during equestrian therapies for the purpose of identifying neurological and hormonal changes. Studies 37,39 conclude that the practice of therapeutic riding increases the alpha wave index and the electromagnetic oscillations which are indicative of stability and relaxation, promoting improved brain function and, therefore, useful in the prevention of ageing-associated neurodegenerative diseases. Furthermore, the study by ${ }^{38}$ analyses the effects of therapeutic riding on hormone levels, which promote psychological benefits by reducing depression levels, stress and behavioural problems. This exercises a positive effect on frame of mind, sleep and agitation due to the increased levels of serotonin and cortisol. Therefore, the use of different animals to interact with the elderly for therapeutic purposes is fundamental in order to study the potential physical, psychological and social benefits.

Due to the usefulness of EAT at a physical and cognitive level, the study conducted by ${ }^{34}$ focuses on the benefits of Hippotherapy in elderly persons with Alzheimer's, being the only study in our analysis to have a sample of individuals with a chronic degenerative disease. It shows the benefits of EAT for this group. Therefore, there is a need for Physical Activity and Sport Science investigators to conduct studies relating to Hippotherapy as a beneficial alternative to physical activity for different users, with and without a disability or previous pathologies. With regard to the study conducted by 40 , this was the only work analysed to use electromyography to evaluate the activation of the stomatognathic muscles (masseter and temporalis) in the elderly before and after participation in Hippotherapy sessions. These muscles, involved in mastication, increase their tension and activation (muscle fibre recruitment) with age-related morphofunctional changes, generating stress and fatigue. The study demonstrates that the Hippotherapy session leads to a reduction in the myoelectric activation of these muscles, which is beneficial. This type of work makes it clear that there is still a long way to go with regard to Hippotherapy-related investigations.
With regard to the experimental study interventions, the sessions had an approximate duration of 30 minutes $^{12,30,36}$. However, in other Hippotherapy studies related to persons with cerebral palsy, the sessions were conducted once a week and with a duration of 45 minutes per session?. It would therefore be recommendable to conduct in-depth studies to compare the benefits achieved based on the duration of the sessions and their maintenance over time. Finally, there is a need to conduct further investigations on the benefits of Hippotherapy and therapeutic riding in the elderly, with larger samples, greater detail on the interventions performed, over longer periods of time and which contain quantifiable and contrastable evaluations, for the purpose of providing greater evidence that will make it possible to recognise Hippotherapy as an effective treatment.

\section{Conclusions}

Following this review of the literature, it can be concluded that Equine Assisted Therapies and Hippotherapy have beneficial therapeutic effects for the elderly if performed progressively and correctly. It is essential for these therapies to be performed by a suitably trained professional, multi-disciplinary team.

Hippotherapy interventions improve static and dynamic balance, postural balance, functional mobility, flexibility, muscle strength, gait, cadence and reduce plasticity. These beneficial effects lead to a lower risk of falls, improving the quality of life of the elderly. Furthermore, they lead to enhanced brain function and increased hormone levels, such as serotonin and cortisol, providing psychological benefits, reducing stress levels, depression and behavioural problems, also improving the quality of sleep and exerting a positive influence on the frame of mind.

Despite the fact that there are few EAT studies and that these are methodologically weak, this type of therapy is recommended in order to achieve biological, psychological and biological improvements.

Finally, the main limitation of the quantitative studies is the small sample size, lack of a control group and no follow-up of the participants, as well as the short duration of the sessions, making it impossible to generalise the results. In another respect, it would be of interest to have in-depth information on the daily habits of the subjects, as this could affect the results of the investigations.

\section{Funding}

This work was partially funded by the Aid to Investigation Groups (GR18170) of the Regional Government of Extremadura (Regional department of Employment and Infrastructures), with a contribution from the European Union through the European Regional Development Funds (ERDF).

\section{Conflict of interests}

Work conducted within the Group for the Optimisation of Sport Performance and Training (GOERD) of the Faculty of Sport Sciences of 
the University of Extremadura. All authors contributed to the preparation of the manuscript and we certify that it has not been published or being considered for publication in another journal.

\section{Bibliography}

1. Del Rosario-Montejo O, Molina-Rueda F, Muñoz-Lasa S, Alguacil-Diego IM. Efectividad de la terapia ecuestre en niños con retraso psicomotor. Neurología. 2014;30:425-32. https://doi.org/10.1016/j.nrl.2013.12.023

2. Uribe AM, Restrepo TF, Yajaira D. ¿Cómo beneficia la Equinoterapia a las personas con síndrome de Down? R CES Salud Pública. 2012;3:4-10.

3. Arias $V$, Arias $B$, Moretin R. Terapia asistida por caballos: nueva propuesta de clasificación, programas para personas con discapacidad intelectual y buenas prácticas. Revista Española sobre Discapacidad Intelectual. 2008;39:18-30.

4. Gámez-Calvo L, Gamonales JM, Silva-Ortiz A, Muñoz-Jiménez J. Benefits of hippotherapy in elderly people: scoping review. J of Human Sport and Exercise, in press. 2020 https://doi.org/10.14198/jhse.2022.172.06

5. Gámez-Calvo L, Silva-Ortiz A, Gamonales JM, Muñoz-Jiménez J. Influencia de la Hipoterapia en la calidad de vida de los niños con síndrome de Down: Revisión literaria. I Congreso Nacional Mujer y Deporte Paralímpico. Universidad de Huelva, Huelva (España). 2019.

6. Villasís-Keever MÁ, Pineda-Leguízamo R. Utilidad de hipoterapia en la parálisis cerebral infantil. R Mexicana de Pediatría. 2017;84:131-3.

7. Fernández-Gutiérrez C, Apolo-Arenas MD, Martínez-García Y, Caña-Pino A. Efectos de la Hipoterapia en la estabilidad postural en parálisis cerebral infantil: a propósito de un caso clínico. Fisioterapia. 2014;37:135-9. https://doi.org/10.1016/j.ft.2014.10.002

8. Vargas J, Patricio L, Solís-Cartas U, Martínez-Larrarte JP, Serrano-Espinosa I. Aplicación de la Hipoterapia en los niños con parálisis cerebral. R Archivo Médico de Camagüey. 2016;20:496-506.

9. López-Roa LM. Efectos de la hipoterapia en posición sedente hacia adelante en un paciente con retraso psicomotor e hipotonía. Memorias. 2011;9:130-7.

10. Muñoz-Lasa S, López De Silanes C, Atín-Arratibel MÁ, Bravo-Llatas C, Pastor-Jimeno S, Máximo-Bocanegra N. Efecto de la Hipoterapia en esclerosis múltiples: estudio piloto en calidad de vida, espasticidad, marcha, suelo pélvico, depresión y fatiga. Medicina Clínica. 2019;152:55-58. https://doi.org/10.1016/j.medcli.2018.02.015

11. De Miguel A, De Miguel MD, Lucena-Antón D, Rubio MD. Efectos de la Hipoterapia sobre la función motora en personas con síndrome de Down: revisión sistemática. $R$ de Neurología. 2018;67:233-41. https://dx.doi.org/10.33588/rn.6707.2018117

12. Araújo TB, Martins WR, Blasczyk JC, Feng YH, Oliveira RJ, Copetti F, Safons MP. Efeito da equoterapia no equilíbrio de idosos: uma revisão sistemática com metanálise. $R$ Brasileña de Ciencia y Movimiento. 2018;26:178-184. https://doi.org/10.31501/rbcm. v26i3.6972

13. White-Lewis S, Russell C, Johnson R, Cheng AL, McClain N. Equine-assisted therapy intervention studies targeting physical symptoms in adults: A systematic review. Appied Nursing Research. 2017;38:9-21. https://doi.org/10.1016/j.apnr.2017.08.002

14. ShurtleffT, Engsberg J. Long-term effects of hippotherapy on one child with cerebral palsy: A research case study. British J of Occupational Therapy. 2012;75:359-366. https:// doi.org/10.4276/030802212X13433105374279

15. Jiménez $\mathrm{A}$. Efectos de las terapias ecuestres en personas con parálisis cerebral. $R$ Española de Discapacidad. 2017;5:171-184. https://doi.org/10.5569/2340-5104.05.02.09

16. Berbes L, Coronados $Y$, Semino L, Andrade JA. Desafíos sociales del envejecimiento de la población. R Cubana de Medicina Física y Rehabilitación. 2018;10:1-3.

17. López-Gómez MP, Marín-Baena RA. Revisión teórica desde la psicología sobre representaciones sociales del envejecimiento y la vejez en Latinoamérica y España 2009-2013. RCientífica General José María Córdova. 2016;14:155-202.

18. McCarthy LH, Bigal ME, Katz M, Derby C, Lipton RB. Chronic pain and obesity in elderly people: results from the Einstein aging study. J of the American Geriatrics Society. 2009;57:115-119. https://doi.org/10.1111/j.1532-5415.2008.02089.x

19. Steves CJ, Spector TD, Jackson SH. Ageing, genes, environment, and epigenetics: what twin studies tell us now, and in the future. Age and Ageing. 2012;41:581-586. http:// dx.doi.org/10.1093/ageing/afs097

20. Carville SF, Perry MC, Rutherford OM, Smith IC, Newham DJ. Steadiness of quadriceps contractions in young and older adults with and without a history of falling. European
J of applied physiology. 2007;100:527-533. https://doi.org/10.1007/ s00421-006-0245-2

21. Mora GS, García R, Perea M, Ladera V, Unzueta J, Patino M, Rodríguez, E. Deterioro cognitivo leve: detección temprana y nuevas perspectivas. R. Neurológica. 2012;54:303-10.

22. Ayalas-Rojas R, \& Soto-Añari M. Indicadores de envejecimiento patológico y lugar de residencia en adultos mayores. $R$ de Psicología. 2017;7:13-24.

23. Ato M, López JJ, \& Benavente A. Un sistema de clasificación de los diseños de investigación en psicología. Anales de Psicología. 2013;29:1038-59. http://dx.doi.org/10.6018/ analesps.29.3.178511

24. Gamonales JM, Gil-Sánchez O, Porro-Cerrato C, Gómez-Carmona CD, Mancha-Triguero D, Gamonales FJ. Psicomotricidad en el aula de Educación Infantil: alumnos con Trastorno de Déficit de Atención e Hiperactividad. RProfesional de Investigación, Docencia y Recursos Didácticos. 2018;100:440-54.

25. Gamonales JM, Muñoz-Jiménez J, León-Guzmán K, Ibáñez SJ. Football 5-a-side for individuals with visual impairments: a review of the literature. European J of Adapted Physical Activity. 2018;11:1-19. https://doi.org/10.5507/euj.2018.004

26. Thomas JR, Silverman SJ, Nelson JK. Research Methods in Physical Activity 7a Ed. Campaing: Human Kinetics. 2015.

27. Benito PJ, DíazV, Calderón MJ, Peinado AB, Martín C, Álvarez M, Morencos E, Pérez J. La revisión bibliográfica sistemática en fisiología del ejercicio: recomendaciones prácticas. RInternacional de Ciencias del Deporte. 2007;3:1-11.

28. Law M, Stewart D, Pollock N, Letts L, Bosch J, Westmoreland M. Guidelines for Critical Review form- Quantitative Studies. Quantitative Review Form-Guidelines. 1998;1-11.

29. O.M.S. - Organización Mundial de la Salud. Informe de la Segunda Asamblea Mundial sobre el Envejecimiento. Madrid, 8-12 de abril 2012. Extraído de http://www.un.org/ es/comun/docs/?symbol=A/CONF.197/9.pp. 85

30. Araújo TB, Silva NA, Costa JN, Pereira MM, Safons MP. Effect of equine-assisted therapy on the postural balance of the elderly. Brazilian J of Physical Therapy. 2011;15:414-9. https://doi.org/10.1590/\$1413-35552011005000027

31. Stergiou A, Tzoufi M, Ntzani E, Varvarousis D, Beris A, Ploumis A. Therapeutic effects of horseback riding interventions: a systematic review and meta-analysis. American J of Physical Medicine \& Rehabilitation. 2017;96:717-25.

32. Stern C, Chur-Hansen A. An umbrella review of the evidence for equine-assisted interventions. Australian J of Psychology. 2019;71:361-74. https://doi.org/10.1111/ ajpy. 12246

33. Aranda-García S, Iricibar A, Planas A, Prat-Subirana JA, Angulo-Barroso RM. Comparative effects of horse exercise versus traditional exercise programs on gait, muscle strength, and body balance in healthy older adults. J of Aging and Physical Activity. 2015;23:78-89. https://doi.org/10.1123/JAPA.2012-0326

34. Borges T, Martins WR, Freitas MP, Camargos E, Mota J, Safons MP. An Exploration of Equine-Assisted Therapy to Improve Balance, Functional Capacity, and Cognition in Older Adults with Alzheimer Disease. J of Geriatric Physical Therapy. 2019;42:E155-E160. https://doi.org/10.1519/JPT.0000000000000167

35. Araújo TB, De Oliveira RJ, Martins WR, De Moura-Pereira M, Copetti F, Safons MP. Effects of hippotherapy on mobility, strength and balance in elderly. Archives of gerontology and geriatrics. 2013;56:478-81; https://doi.org/10.1016/j.archger.2012.12.007

36. Kim SG, Lee CW. The effects of hippotherapy on elderly persons' static balance and gait. J of physical therapy science. 2014;26:25-7. https://doi.org/10.1589/jpts.26.25

37. Sung-Hyon C. Effects of horseback riding exercise on the relative alpha power spectrum in the elderly. Archives of Gerentology and Geriatrics. 2017;70:141-7. https://doi. org/10.1016/j.archger.2017.01.011

38. Sung-Hyoun S, Jin-Woo K, Seon-Rye K, Byung-Jun C. Effects of horseback riding exercise therapy on hormone levels in elderly persons. J of physical therapy science. 2015;27:2271-3. https://doi.org/10.1589/jpts.27.2271

39. Kim SR, Cho SH, Kim JW, Lee HC, Brienen M, Cho BJ. Effects of horseback riding exercise therapy on background electroencephalograms of elderly people. Journal of physical therapy science. 2015;27:2373-6. https://doi.org/10.1589/jpts.27.2373

40. De Mello EC, Regalo SC, Diniz LH, Lage JB, Ribeiro MF, Bevilacqua DE, et al. Electromyographic analysis of stomatognathic muscles in elderly after hippotherapy. PLOS ONE. 2020;15: e0238036. https://doi.org/10.1371/journal. pone.0238036 